\title{
LANGUAGE TEACHING FOR THE NEW SOUTH AFRICA ${ }^{1}$
}

\author{
Stanley G M Ridge
}

This paper describes some of the challenges facing the language teacher as South Africa moves into a new era. The discussion is structured around three areas of change: change in the country, changes brought about by the official language policy, and changes in the school system itself. It explores the implications for language teaching of four key words of the new era: inclusive, non-racial, democracy, and empowerment. In relation to the 11 official languages policy, it examines the status of English, language development issues, linguistic standards, the role of grammar in teaching, and the politics of language and cultural identity. Three areas of teacher need arising from the multicultural classroom are highlighted: understanding the cultural and linguistic diversity of the class, ongoing language learning as essential experience, and developing teaching practices which accommodate diversity as an asset.

In hierdie artikel word sommige van die uitdagings vir die taalonderwyser in 'n veranderende Suid-Afrika beskryf. Die bespreking word om drie veranderingsgebiede gestruktureer: maatskaplike veranderinge, veranderinge meegebring deur die amptelike taalbeleid en veranderinge in die skoolstelsel. Vier sleutelwoorde van die nuwe bedeling in Suid-Afrika inklusief, nie-rassig, demokrasie, en bemagtiging - word ontleed met die oog op hulle implikasies vir taalonderrig. M.b.t. die 11 amptelike talebeleid, word die status van Engels, taalontwikkelingsaspekte, taalstandaarde, die rol van grammatika in die onderwys, en die politiek van taal en kulturele identiteit ondersoek. Drie behoeftes van onderwysers t.o.v. die multikulturele klaskamer word uitgelig; om die kultuur- en taalverskeidenheid van die klas te verstaan, die voortgesette aanleer van ander tale as kernondervinding en die ontwikkeling van onderrigpraktyke waarin diversiteit as 'n bate beskou word.

The changes brought about by the first democratic elections in South Africa in April 1994 are generally cause for much hope. South Africans continue telling one another that we belong together - that there is room for all of us - that we are not going to be held hostage to our past. And we have a firm commitment from the government to giving substance to the new vision. The times, they are a-changing. And the conditions for really desirable change are unusually good.

On the other hand, for all the gratifying changes in the country, we are a long way from realising the vision of a new South Africa. The challenges for the teacher are daunting. There are large adaptations to be made. Conditions in schools and classrooms are changing rapidly, 
not always obviously for the better. And there is no clear path ahead. How, then, do we meet our professional obligations? As educationalists, we tend to privilege the rational. We want things to be logical and orderly. Traditional scientific method aims to limit variables so that it is able to focus on one area and draw reasonably reliable conclusions about it in a systematic way. Yet so few of the variables in our situation have crystallised out that we have to live with much more uncertainty than we would like to.

Our situation, of course, is not new. The figure of Logic or Research in medieval iconography is depicted as a huntress about to enter the wild wood. In a version which I know well (Hussey 1968: 81) ${ }^{2}$ her two dogs are Truth and Falsehood, giving her a 50:50 chance of flushing out the right thing. And her sandals, which keep her feet from the hard realities of the earth, are Fallacy in discourse and Fallacy outside discourse. She can hardly put a foot right. To top it all, the problem which she faces and has to pursue is clearly labelled Insoluble yet Obligatory.

Most of the problems we are obliged to face are, in fact, insoluble. Yet that need not daunt us. No one can, ultimately, solve problems like these. Our approach to them has to be led as much by intuition as by any sharpened intellectual skills. In fact, we may be conceptualising them wrongly by referring to them as problems. In addressing the challenging issues of our time, we have to use our knowledge. But we also have to feel our way. And, as we do these two things, we come to terms with the issues, making some advances, and registering and participating in wider changes in the process.

There are three main areas of change which it will be useful to focus some attention on:

- Our country has changed, is changing and must change more.

Our sense of language and our sense of our linguistic obligations are radically affected by the change in status of our languages, and the goals set by the 11 language policy.

Our school system is facing changes whose implications are, as yet, hardly imagined, particularly those relating to the multicultural, multilingual classroom.

The changes in our country are away from apartheid to an inclusive, non-racial democracy; away from inherited, exploitative colonial relationships to empowerment. At every step, these changes have challenging implications for the language teacher. However, the seductive perils of "political correctness" threaten our ability to come to grips with them. It is vital that we avoid making pious noises, and concentrate rather on how to respond to the challenges in practice. Let us look at some of the key terms. 
Inclusive: In a country with a more highly developed vocabulary of exclusion than most other places in the world, the language teacher must clearly make another vocabulary available to learners, simultaneously fostering inclusive social practices which make that vocabulary useful. Race, class, and gender inclusivity is what we are concerned with. We too readily avoid one part of this cluster by latching onto other parts. Even if we are as open as can be, there are pitfalls in each area. What we need to bear in mind if we wish to avoid the traps is that the inclusivity is for the purposes of democratic living: it is an inclusivity that means we are prepared to hear one another, and openly expect one another to exercise democratic rights. Such an attitude, or the lack of it, is echoed even in the language we ourselves use in the classroom. Douglas Barnes and others have opened up this whole area for our consideration. ${ }^{3}$ No aspect could be more intimately important for the teacher in the multicultural classroom.

Non-racial: Within a particular cultural community there is always a good bit of valueladen shorthand. Often this is useful, or innocuous. But a good deal of unpacking of racist values may be necessary in the language classroom. It is not that the teacher should preach on this, but rather that we should cultivate an awareness of the values embedded in particular language usages and provide real alternatives. This will require an alertness to such usage in common practice. First of all in our own practice. Not so that we keep out of trouble, but so that we grow in our understanding of the ways in which language works, and become better, more facilitative teachers as a result. Then, we have to be sensitive to the value systems in public discourse, such as is used in the newspapers and electronic media, which have a kind of public sanction and authority. Finally, we need to hear the racial undertones in interactional discourse in the classroom. Finding non-racial discourses which nevertheless leave room for the appreciation of cultural diversity is not a product of good or disciplined behaviour. Rather, command of such discourses is to be attained only by taking the need seriously and working at the matter from conviction. If we believe non-racialism is important, we will naturally latch onto or develop ways of speaking which are consistent with it.

Democracy: Democratic language and practice invite response and participation. They reflect a real respect for the other person, at best as someone worth listening to, and at least as someone whose rights have to be respected. In many classrooms and indeed schools, such an ethos has been absent. The shift to democracy alters relations of power and authority in the classroom as elsewhere. One of the more obvious implications for teaching is that democratic education privileges discussion and negotiation. The teacher as gatekeeper to a fixed body of knowledge gives way to the teacher as someone responsible for cultivating learning. This is a highly sophisticated task, not made simpler by the fact that it is not only the teacher who has to change. Democratic values require mutual respect and tolerance between learner and teacher. And one of the major challenges facing the teacher in the classroom of the immediate future is going to be enabling learners to work through some half-baked versions of democracy which have been doing the rounds, and develop a sense of the mutuality which is democracy's most distinctive characteristic. 
- Empowerment: This sounds good. What better aim of a liberatory pedagogy than empowerment? Yet, it is important that we be much clearer about what the education we are offering should empower our students to do. We can specify some things, which would probably apply also in New York, Beijing and Buenos Aires. However, we need also to develop from within ourselves, and for the particular people we are teaching, a sense of the specific disempowerments of our history. Then we can work at what can be done to reverse them. In this regard, the deeply challenging work of Paulo Freire has to be considered. Teaching language is in a sense teaching people to be able to change their world. The title of a book which Freire wrote with Donald Macedo suggests this dimension: Literacy: Reading the Word and the World (Freire and Macedo 1987). Taking a lead from him we might answer the question: "What are we teaching languages for?" by saying that we are empowering our students to learn, to respond adequately to new situations, to change their world, and to be able to continue doing so.

There is, however, another valid response to the question: "What are we teaching languages for?" A more specific response does not necessarily lead us in the direction of a narrow instrumentalism. We need to be concerned with specifics. Purpose, considered in a sophisticated way, can be an excellent filter, and can throw the unexpected into relief, separating conventional wisdom and real insight. Why do second language English students in a specific province, who are going into the job market after Std 7, need the language? The answers will not all necessarily be the same if we ask this question of Xhosa or Afrikaans. Moving to those who are continuing to Std 10 , we will find the balance of answers shifting very significantly. One thing is clear, though. All second language teachers, and particularly teachers of African languages, have to keep applying their minds to how learners can be enabled to use the languages in ordinary conversation and for the purposes which are important to them. I was taught Zulu at school. I was also taught Latin. I have to say that Zulu was decidedly the deader language. No one observing a lesson would have dreamed that half the pupils in the class could speak Zulu fluently and that Zulu was spoken every day in our immediate environment. For us, Zulu was a school subject, removed from the real world. Clearly South Africans cannot afford to have situations like that continue.

The second major source of change is the eleven language policy, and the shift in status which it effects. Held before us is the ideal of the full development of all South Africa's languages. Many will welcome this. But whatever we think of it, we are obliged to work to that end. As we consider this task seriously, we shall find it throwing up a variety of challenges, many of them unanticipated. 
First, we have to consider the role of English, and to a significant extent Afrikaans also. It is often argued that English is the language of access. In a very important sense this is true. However, the sentence requires completion, rather like the old advertisement for a laundry powder which "washes whiter". Access to what? Certainly, English offers access to the international world of learning and commerce. But there are many things in social and political relations within the country to which it does not offer any access at all for large numbers of people. And at certain stages there are fundamental abilities which may best be developed in the first language. At a time when Latin was the main language of access to learning for English people, Geoffrey Chaucer the poet wanted to explain some science to his young son, Lewis. He did so in English. And his reasons echo for us in South Africa today. He says to his son:

May these true conclusions in English serve you as well as these same conclusions in Greek serve noble Greek scholars, and in Arabic the Arabians, in Hebrew the Jews, and in Latin the Latin folk. These Latin folk (in their turn) found these conclusions in various other languages, and translated them into their own tongue, that is to say, Latin. And God knows that in all these languages and in many more these conclusions have been adequately learned and taught. (Chaucer 1966: 545)

May these true conclusions in Xhosa serve you as well as these same conclusions in English serve English speakers ....?

Secondly, development of South African languages is not a euphemism for development of African languages. English and Afrikaans must also develop for new purposes. English in South Africa will always feel the pull of English world wide, but it must also be different. Noah Webster, the American dictionary compiler, wrote of American English in 1783:

For America in her infancy to adopt the present maxims of the old world, would be to stamp the wrinkles of decrepit age upon the bloom of youth and to plant the seed of decay in a vigorous constitution. (Partridge 1968:197)

Such chauvinism will not, one hopes, drive our project. Nevertheless, it is inevitable that questions of standard in English and Afrikaans will be much debated in the years ahead, and that teachers will have a large part in arbitrating and negotiating acceptable usage.

Thirdly, related both to arguments about standards and to the question of language as part of the project of national reconstruction is the old issue of grammar or no grammar - or how grammar (if that is grammatical). It is worth reminding ourselves how old the issue is. The arguments date back to classical times and have recurred periodically since. Allow me to quote two statements from the 18th century and you will, I think, find yourselves on familiar ground. In 1762, Bishop Robert Lowth declared with simple rectitude that:

The principal design of a Grammar of any Language is to teach us to express ourselves with propriety in that Language; and to enable us to judge of every phrase and form of construction, whether it be right or not. The plain way of doing this is, to lay down rules, and to illustrate them by examples. But beside showing what is right, the matter may be further explained by pointing out what is wrong. (Partridge 1968:189) ${ }^{6}$ 
A few years later, in 1776, George Campbell took his cue from Horace in presenting the counter case:

It is not the business of grammar, as some critics seem preposterously to imagine, to give law to the fashions which regulate our speech .... It is of no consequence here to what causes originally these modes or fashions owe their existence . . ., they no sooner obtain and become general, than they are laws of the language, and the grammarian's only business is to note, collect and methodise them. (Partridge 1968:192) ${ }^{7}$

One of the less useful parts of our heritage from the 18th century enlightenment is that we are inclined to think in binary terms about such matters - either this or that - and exclude other possibilities or combinations. The pressure of demand will now force us to be more pragmatic. From the point of view of the general democratic public, we are there to give access to languages so that they can be used. Our job is to find ways of making this possible. The role of grammar has to be found in that context. The fourth area of concern is the politics of language and cultural identity. The fears about language issues which can be seen in proclamations that Afrikaans is being squeezed out, and that English will not be available as a first language have some validity. Some. It is also true that cultural and linguistic affirmation may be an important social necessity for communities. Clearly, the teacher will be called on to help, within and outside the classroom, both to provide affirmation, and to steer language movements away from attenuating exclusivism. My language and culture first. must not become My language and culture only.

The third main source of change is the situation in the school and the classroom. Some schools have dealt with issues of multilingualism and multiculturalism for years. For most, however, it is newly recognised as a phenomenon. Inevitably, the language teacher is in the middle. I think there are three main implications:

Every language teacher has a duty to develop a sense of the languages and cultures active in the school or institution. This for several reasons. First, to have a better idea of the teaching context and the resources which may be to hand. Second to affirm the other languages by reference and elicitation. Third to be a resource to other teachers in the school.

Now more than ever before, it is desirable that every teacher should become a learner of language. As we learn the languages of others in our situation, we almost inevitably come to a new sympathy and understanding of the experience of our own students. We should also find the frustration and joy of knocking at the door of another culture, and realising something more of what it means to be a South African. 
Language teachers are under an obligation to adopt or develop teaching practices which can accommodate the social and linguistic variety in the classroom as an asset. We all know that it can be a liability. It is also, undoubtedly a major asset. The rigidity of the old approaches has to go. And we have to develop the new with all the skill at our disposal.

By way of pointing you to what is on our horizon, I must now conclude by taking you back a little in our own history. In July 1934 there was a major international conference in Cape Town on "Educational Adaptations in a Changing Society". Most speakers anticipated rapid change. And many were saying sixty years ago the same kinds of things as we are saying today. It is salutary to see what we have failed to give due attention to. As we face the future, I commend to you some words of the famous American philosopher, John Dewey, spoken in Cape Town on that occasion:

Departure from the rigidity of the old curriculum is only the negative side. If we do not go on and go far in the positive direction of providing, through persistent intelligent study and experiment, a body of subject-matter much richer, more varied and flexible, and also more definite in terms of the experience of those being educated, we shall tend to leave an educational vacuum in which anything may happen. (Dewey 1937: 26)

\section{NOTES}

This paper was presented in an earlier form as the opening address at the annual conference of the South African Association of Language Teachers in July 1994. The style still reflects a public engagement with a group of people with shared concerns and obligations.

The illustration is from G Reisch, Margarita philosophica, 1508, reproduced and described in Hussey 1968: 81

Most usefully, perhaps, in Douglas Barnes: 1976. The work of Harold Rosen and Douglas Holly in Britain, and the OISE group in Canada is very helpful in exploring this area.

Geoffrey Chaucer, "A Treatise on the Astrolabe," in Chaucer 1966: 545. Freely rendered into modern English here by S G M Ridge.

Noah Webster, A grammatical institute of the English language, 1783, quoted Partridge 1968: 197.

Bishop Robert Lowth, Short introduction to English grammar, 1762, quoted Partridge 1968: 189.

George Campbell, The philosophy of rhetoric, 1776, quoted Partridge 1968: 192. Campbell's ideas derive ultimately from Horace's radical dictum of 18 centuries before: "use is the sole arbiter and norm of speech" (quoted Partridge 1968:191). However, there were English precedents of considerable standing. Partridge (1968: 23) remarks that for George Puttenham, whose Arte of English Poesie appeared in 1589, "The criterion ... was always decorum; it did not depend on the approval of grammarians, but on the place, time and purpose of the pronouncement." 


\section{REFERENCES}

BARNES, D. 1976. From communication to curriculum. Harmondsworth: Penguin.

CHAUCER, G. 1966. A treatise on the astrolabe. In Robinson, F N (Ed.), The Works of Geoffrey Chaucer. London: Oxford University Press. 544-563.

DEWEY, J. 1937. The need for a philosophy of education. In Malherbe E G (Ed.), Educational adaptations in a changing society. Cape Town: Juta: 22-28.

FREIRE, $\mathrm{P}$ and D MACEDO. 1987. Literacy: reading the word and the world. London: Routledge and Kegan Paul.

HUSSEY, M. 1968. Chaucer's world: a pictorial companion. Cambridge: Cambridge University Press.

PARTRIDGE, A C. 1968. Tudor to Augustan English: a study in syntax and style from Caxton to Johnson. London: André Deutsch. 